DOI https://doi.org/10.32837/app.v0i67.1169

УДК 327.8

О. Б. Соколовський

orcid.org/0000-0002-0515-2367

аспірант кафедри політології та міжнародних відносин

Національного університету «Львівська політехніка»

\title{
ОСОБЛИВОСТІ ЗАХИСТУ ПРАВ НАЦІОНАЛЬНИХ МЕНШИН У РЕСПУБЛІЦІ ПОЛЬЩА
}

Розпад Радянського Союзу та Організації Варшавського договору ознаменувався новим етапом в історії держав Центрально-Східної та Східної Європи. До того ж карта Свропи кардинально змінилася після Другої світової війни, державні кордони встановлювалися з огляду на стратегічне значення та певними домовленостями, що доволі часто означало вимушене проживання частини однієї нації на території іншої. Республіка Польща - одна $з$ найпрогресивніших держав $Є С$, має не тільки чималу кількість національних меншин на своїх теритоpiï, але і досвід щодо їх захисту та надання прав.

У польській юридичній науці одним з основних визначень меншин є визначення Агнешки Маліцької, яка вказала, що, беручи до уваги дефініції, розроблені у міжнародному праві, можна припустити, що поняття меншини описує групу людей, громадян іншої держави, які залишаються у меншості щодо решти громадян і відрізняються від більшості іншою національністю, культурою, традицією, мовою, часто також релігією чи расовим походженням. Ця група також відрізняється підкресленням своєї іншості, вона не прагне до асиміляції, а навпаки, плекає свою культуру, мову чи релігію, намагається зберегти та культивувати власну національну ідентичність та інше (Malicka A., 2015)

Першим важливим кроком, який було зроблено у Республіці Польща щодо захисту прав національних меншин, стала двостороння угода зі Чехословаччиною, підписана ще 10 березня 1947p. Договір про спільну і взаємну допомогу між Республікою Польща та Чехославаччиною, де в окремому протоколі були зазначені права національних меншин, був доволі незвичним для держав того часу, які перебували під впливом Радянського Союзу.

Нетиповий характер цього протоколу був наслідком того, що до змін, що відбулися 1989 р., питання національних меншин ігнорувалися, оскільки вважалися внутрішньою справою кожної держави. При цьому слід відзначити, що тогочасні двосторонні угоди, укладені на європейському континенті, визначали лише регулювання громадянства та переміщення людей, а не права національних меншин. Хоча термін «національні меншини» був вжитий вкрай стисло у цьому протоколі, але він став умовою дружніх та товариських стосунків між сторонами аж до 1991р. Угода передбачала цілеспрямоване надання полякам у Чехословаччині та чехам і словакам у Польщі рівних можливостей національного, політичного, культурного та економічного розвитку. (Ganowicz, E. 2015)

Республіка Польща взяла за основу принципи, які були вказані у договорі, а саме принцип взаємності та «принцип верховенства права», що потрібно розуміти як вказівку на реалізацію прав за чинним правовим порядком кожної із сторін договору. Наступні договори зі своїми сусідами Польща почала укладати аж після 1990 р.

Зобов' язання щодо захисту прав національних меншин були включені в угоди про дружбу та співпрацю між Республікою Польщею та 15 державами Європи. Зобов' язання держав-учасниць договорів містять більш ширший обсяг захисту прав національних меншин, зокрема вказуючи на право на:

- вивчення рідної мови, вільно користуватися нею в приватному громадському житті;

- використання свого імені та прізвища у звучанні рідної мови;

- визнання та можливість сповідувати свою релігію;

- створення власних громадських організацій та асоціацій;

- підтримку контактів між представниками національних меншин та країною їх етнічного походження. 
Конституція Республіки Польща у ст. 35 гарантує національним та етнічним меншинам право підтримувати власну культуру, мову та звичаї. Таким чином, польська влада вирішила спеціально врегулювати становище групи осіб, які відрізняються своїм етнічним чи національним походженням. Як і в більшості демократичних країн світу, значна частина гарантій у Польщі пов' язана з мовою окремих громад. Саме на основі цих нормативних актів розвинулася концепція мовних прав. (Prawa mniejszości narodowych i mniejszości etnicznych w prawie międzynarodowym i polskim, 2011)

Концепція мовних прав складається з низки гарантій, що дозволяють представникам національних та етнічних меншин дбати про збереження власної мови.

Тут варто згадати, наприклад, право на освіту мовою меншини або право користуватися нею з адміністрацією місцевого самоврядування. Однак ця стаття присвячена двомовній географічній номенклатурі. Через те, що це стосується як представників меншин, так і інших громадян держав, воно часто стає предметом широких публічних дискусій.

Рамкова конвенція про захист національних меншин передбачає, зокрема, відповідно до положень статті 15 забезпечення умов для фактичної участі осіб, що належать до національних меншин, у державних справах, особливо тих, що їх стосуються. Заради втілення цієї політики Польща ініціювала створення специфічного органу - Спільної комісії. Спільна комісія - це орган, в якому національні та етнічні меншини отримали своє представництво та фактичний вплив на формування політики державної адміністрації щодо меншин та ії реалізацію (Banach-Gutierrez, Jablonski, 2017).

Основним завданням Спільної комісії як дорадчого органу є надання висновків щодо заходів із реалізації прав меншин та програм розвитку культурної ідентичності меншин. Спільна комісія видає висновки щодо правових актів, які стосуються меншин, а також має певні важелі впливу, які дозволяють впливати на зміст відповідних правових норм. Спільна комісія видає висновки щодо принципів розподілу коштів із державного бюджету, які спрямовуються на діяльність, що підтримує захист прав меншин та розвиток їхньої культурної самобутності. Комісія має повноваження проводити моніторинг та протидіяти дискримінації осіб, що належать до національних та етнічних меншин. Для виконання своїх статутних завдань Комісія може співпрацювати з компетентними органами державного управління та місцевого самоврядування, а також з організаціями меншин.

На підставі ст. 24 до складу Спільної комісії входять: представники органів державного управління, а також представники всіх національних та етнічних меншин та меншин, що використовують регіональну мову. Кандидатів пропонують організації національних та етнічних меншин, яких ті повинні затвердити (Prawa mniejszości narodowych i mniejszości etnicznych w prawie międzynarodowym i polskim, 2011).

3 боку органів державного управління до складу Спільної комісії входять міністр державного управління, міністр культури та охорони національної спадщини, міністр освіти та виховання, міністр державних фінансів, міністр праці, міністр юстиції, міністр внутрішніх справ, міністр соціального забезпечення, міністр закордонних справ та міністр президента Центрального статистичного управління і керівник канцелярії прем' єр-міністра.

Кількість представників національних меншин визначається на основі критерію їх кількості. Численні меншини отримали два місця у складі Спільної комісії, а менш численні меншини - одне місце. Крім того, до складу Комісії також входять два представники громади, які використовують регіональну мову.

Засідання Спільної комісії проводяться не рідше одного разу на півроку. Позиція Комісії розробляється на основі домовленості сторін, а не голосування. Також передбачається можливість засідань лише частини Комітету, тобто окремих засідань представників національних та етнічних меншин та окремих засідань представників органів державного управління. Також у рамках Спільної комісії існує три специфічних групи: з питань освіти, культури та ЗМІ та 3 питань ромів (Савицький, 2012).

Діяльність Спільної комісії є одним із елементів реалізації конституційного обов' язку органів державної влади гарантувати відповідні інструменти захисту статусу національних та етнічних меншин у Польщі. Незважаючи на те, що Комісія не має власних інструментів, 
що слугують вищезазначеним цілям, і є органом, що формує думки, та дорадчим органом, вона дійсно впливає на рішення та ініціативи, що здійснюються польським законодавством. Склад Комісії на урядовій стороні, тобто група з 10 міністрів, схоже, підтверджує, що захист національних та етнічних меншин є важливим завданням для органів державної влади.

Хоча слід відзначити, що у 2016 році було проведено загалом п' ять засідань Комісії. Таким чином, з цього випливає, що мінімальні стандарти, встановлені законодавством, можуть бути дещо змінені, беручи до уваги кількість зобов'язань, що здійснюються окремими групами, що діють у складі Комісії, а також пріоритети державної політики щодо меншин.

Чимало польських науковців вважають, що каталог компетенцій повинен бути розширений таким чином, щоб Комісія, крім своїх дорадчих повноважень, могла самостійно реалізовувати проекти, які вона вважає необхідними для забезпечення всебічного захисту національних та етнічних меншин у Польщі.

Більш осучаснений закон у Республіці Польща щодо захисту прав національних меншин було прийнято 6 січня 2005 року. Закон містить 40 статей, де було виокремлено поняття «національні меншини», а також регулювання їх прав та свобод та статус регіональних мов. Так, у статті 2 цього закону було визначено, що національною меншиною слід вважати:

1) чисельно меншу групу, яка проживає на території Польщі;

2) групу осіб, яка відрізняється культурою, мовою та релігією від решти населення Польщі;

3) групу осіб, які прагнуть зберегти свою культурну та етнічну особливість та ідентичність;

4) групу осіб, які ототожнюють себе з народом власної держави, які усвідомлюють історію національного походження.

Виходячи із цього визначення, можна зробити висновок, що явище національних меншин у Польщі розглядається доволі широко. Окрім цього, у законі було визначено, які етнічні групи слід відносити до національних меншин, які проживають у Польщі. Сюди відносять:

- білорусів;

- чехів;

- литовців;

- німців;

- вірмен;

- росіян;

- словаків;

- українців;

- євреїв.

Також закон визнавав національними меншинами караїмів, лемків, ромів, татар та кашубів (Ustawa z dnia 6 stycznia 2005 r. o mniejszościach narodowych i etnicznych oraz o języku regionalnym, 2005).

Прийняття подібного закону не було чимось неочікуваним, оскільки Польща давно розвивала цю політику та намагалася ï підтримувати. Влада Польщі продовжує розглядати національні меншини як спосіб посиленої та ефективної транскордонної співпраці. Попри це, слід відзначити, що прийняття згаданого вище закону було хоч і очікуваним, але затребуваним кроком, якого очікувала ЄС від держав Вишеградської групи.

Незважаючи на це, закон мав доволі неочікуваний критерій, який не кожного відносив до національної меншини, а саме проживання предків на сучасній території Республіки Польща щонайменше 100 років. Виходячи із цього положення, громадянин іншої держави, який приїхав та зміг отримати паспорт громадянина Республіки Польща, не підпадав під критерій віднесення до національних меншин.

Ще одним важливим моментом внутрішнього статусу національних меншин є питання кашубів та сілезців, а також регіональної мови. Питання регіональної мови розглядається в Розділі IV закону і включає в себе два основних критерії:

1) мова, що традиційно використовується на території держави громадянами, які відносяться до чисельно меншої групи від населення Польщі;

2) відрізняється від державної мови Польщі.

Виходячи із цього, влада Польщі довгий період часу не йшла на поступки щодо визнання мови кашубів та силезців до регіональної мови. Кашуби - західнослов янський народ, чисель- 
ність його становить 200 тис., сконцентрований він в основному на півночі Польщі (Картузи та Гдина). Сілезці - ще один слов янський народ, що проживає на півдні Польщі, а також у Чехії та Словаччині, також має власну культуру і мову. Так, під час перепису 2011 року в Польщі 850 тис. осіб назвали себе сілезцями (Стрийський, 2016).

Уряд Польщі довгий період часу відмовлявся визнавати представників цих груп національними меншинами та надавати статус їхній мові як регіональній. Така тверда позиція була пов язана з ідеологічно запровадженим підходом до національних меншин, зокрема до кашубів та сілезців, закладеного ще Юзефом Пілсудським. Основним аргументом виступало те, що кашубська та сілезька мова - це лише діалекти або говірки польської.

Ситуація дещо змінилася для кашубів на краще в 2005 році із прийняттям закону «Про національні та етнічні меншини та про регіональну мову». Сілезія, попри значно більшу чисельність населення, залишається аутсайдером цього процесу, хоча і були чималі сподівання, що ситуація зміниться за прем'єрства Дональда Туска, який є одним із кашубів та мав би розуміти прагнення іншої меншини на здобуття своїх прав.

Також слід згадати іншу етнічну групу, яка тісно пов язана з Україною та $є$ доволі численною у Польщі, а саме лемків. Лемки традиційно населяли райони Низьких Бескидів та Сандєцьких Бескидів. Виділення лемків як етнічної меншини досі залишається суперечливим у Польщі. Незважаючи на свою етнічну, культурну та релігійну близькість, лемки суттєво відрізняються від української нації, розвиваючи деякі окремі риси, такі як, наприклад, видозмінені імена та використання лемківського діалекту, культурна та деяка історична відмінність.

Інша національна меншина, яка теж має певні особливості, - це євреї. Євреї - це національна меншина, чисельність якої за переписом 2011 року становила близько 7,5 тис. осіб. Колись Польща була другою домівкою для єврейського народу, внаслідок Другої світової війни кількість євреїв різко зменшилася. Після 1989 р. У Польщі відбулося відродження єврейського життя, багато післявоєнних емігрантів повернулися до своїх коренів, були створені організації, що працюють на розвиток цієї громади в Польщі (Гладієвський, 2013).

Як лемки, так і єврейські меншини активно використовують права, надані їм законодаством. Зокрема, ці етнічні групи мають право створювати власні освітні, культурні інституції, а також організації, спрямовані на захист релігійної ідентичності. Сврейська меншина користується цими правами, створюючи навчальні заклади. У 2014/2015 навчальному році 418 учнів, які належать до цієї меншини, вивчали іврит у 8 навчальних закладах (у Варшаві та Вроцлаві).

Важливо відзначити активну діяльність лемків Польщі щодо організації різноманітних транскордонних заходів. Прикладами таких заходів є «Лемківська ватра» у Здині, Міжнародний фольклорний фестиваль національних та етнічних меншин «Свят під Кичера», «Міжнародна бієнале лемківської культури» у Криниці або «Зустрічі з лемківською культурою» у Гожуві-Великопольському у справі лемківської меншини та фестивалю (Współpraca transgraniczna w Europie, 2003, c. 167-170)

Отже, Республіка Польща є вкрай мультукультуральною, до їі населення входять такі національні меншини, як українці, білоруси, росіяни, німці, чехи, словаки, роми, євреї, литовці, а також лемки, сілезці та кашуби. Польща активно співпрацює з державами-сусідами щодо захисту прав національних меншин та активно долучає їх до транскордонної співпраці. Так, Польща є активним учасником регіонального інструменту СС-єврорегіонів, зокрема єврорегіонів «Балтика», «Бескиди», «Буг», «Карпати», «Татри» та багатьох інших. Рівень захисту прав національних меншин в Польщі є доволі високим, а ініціатива щодо захисту прав національних меншин через створення Спільної комісії, до якої входять міністри та високопосадовці 3 однієї сторони та представники національних меншин - 3 іншої, дає високі шанси на порозуміння та ефективний і правомірний розвиток національних меншин Республіки Польща. 


\section{Література}

Гладієвський, П. (2013). Регіональна мова: польський досвід. Відновлено 3: https:/ / zbruc.eu/node/7562. Савицький, Ю. (2012). Мовні пристрасті у Польщі: сілезці хочуть регіональної мови. Відновлено з: https://www.radiosvoboda.org/a/24694575.html.

Стрийський, I. (2016). Національні меншини в Польщі: хто крім українців?. Відновлено з: https://naszwybir.pl/28921-2.

Banach-Gutierrez, J., JablonskiM. (2017). Aktualne problemy ochrony wolności i praw mniejszości w Polsce i naświecie. Pobranez: http://www.bibliotekacyfrowa.pl/Content/79764/Aktualne_problemy_ochrony_wolnosci_i_praw.pdf.

Ganowicz, E. (2015). Mniejszosci naroowe I etniczne w Polscea bezpieczenstwo panstwa. Pobranez: https://journals.indexcopernicus.com/api/file/viewByFileId/149602.pdf.

Malicka A. (2015). Niemecko-polska szkola prawa Pobranez: https:/ /wuwr.pl/ppa/article/view/7484/7130.

Prawa mniejszości narodowych i mniejszości etnicznych w prawie międzynarodowym i polskim. (2011). Pobranez: https://www.senat.gov.pl/gfx/senat/pl/senatopracowania/17/plik/ot599.pdf.

Ustawa z dnia 6 stycznia 2005 r. o mniejszościach narodowych i etnicznych oraz o języku regionalnym. Dz.U. 2005 Nr 17 poz. 141. (2005). Pobranez: http://isap.sejm.gov.pl/isap.nsf/DocDetails.xsp?id=WDU20050170141. Współpraca transgraniczna w Europie. (2003). Pobranez: https://wroclaw.stat.gov.pl/cps/rde/xbcr/wroc/ ASSETS_14-19.pdf.

\section{References}

Hladiievskyi, P. (2013). Regionalna mova: polsky i dosvid. [Regional language: polish experience] Retrieved from: https://zbruc.eu/node/7562.

Savytskyi, Yu. (2012). Movni prystrasti u Polshchi: sileztsi khochut rehionalnoi movy. [Language preferences in Poland: silezian want regional language] Retrieved from: https://www.radiosvoboda.org/a/24694575. html [in Ukrainian].

Stryiskyi, I. (2016). Natsionalni menshyny v Polshchi: khto krim ukraintsiv?. [National minorities in Poland: who else beside Ukrainians?] Retrieved from: https://naszwybir.pl/28921-2/ [in Ukrainian].

Banach-Gutierrez, J., JablonskiM. (2017). Aktualne problemy ochrony wolności i praw mniejszości w Polsce i naświecie. [Actual problems of freedoms and laws of national minorities in Poland and world] Retrieved from: http://www.bibliotekacyfrowa.pl/Content/79764/Aktualne_problemy_ochrony_wolnosci_i_praw. pdf [in Polish].

Ganowicz, E. (2015). Mniejszosci narodowe I etnicznew Polscea bezpieczenstwo panstwa. [National and ethnical minorities in Poland state security] Retrieved from: https://journals.indexcopernicus.com/api/file/ viewByFileId/149602.pdf [in Polish].

Malicka A. (2015). Niemecko-polska szkola prawa [German-polish school of law] Retrieved from: https://wuwr.pl/ppa/article/view/7484/7130.

Prawa mniejszości narodowych i mniejszości etnicznych w prawie międzynarodowym i polskim. (2011). [Rights of national and ethnical minorities in law of Poland and world] Retrievedfrom: https://www.senat. gov.pl/gfx/senat/pl/senatopracowania/17/plik/ot599.pdf[in Polish].

Ustawa z dnia 6 stycznia 2005 r. o mniejszości nachnarodowych i etnicznych oraz o języku regionalnym. Dz.U. $2005 \mathrm{Nr} 17$ poz. 141. (2005). [Act of national and ethnical minorities and regional language from 6 january 2005] Retrieved from: http://isap.sejm.gov.pl/isap.nsf/DocDetails.xsp?id=WDU20050170141[in Polish].

Współpraca transgraniczna w Europie. (2003). [Crossborder cooperation in Europe] Retrieved from: https://wroclaw.stat.gov.pl/cps/rde/xbcr/wroc/ASSETS_14-19.pdf[in Polish].

\section{Анотачія}

Соколовський О. Б. Особливості захисту прав національних меншин у Республіці Польща. Стаття.

У сучасних умовах національні меншини стали невід'ємною частиною міжнародних відносин. Після розпаду СРСР та Варшавського договору західні держави вкрай сильно переживали, щоб на території колишньої російської імперії на відбувалося етнічних конфліктів, які б могли перерости у повномасшабні війни. Попри побоювання Заходу, держави Центрально-Східної Європи вміло змогли вийти із ситуації, а національні меншини стали ключем для поглибленної транскордонної співпраці та ключем для налагодження дружніх відносин із державами-сусідами. Республіка Польща є однією з найуспішніших держав Центрально-Східної Європи, в тому числі і в забезпеченні прав національних меншин. Польща є активним учасником транскордонної співпраці в рамках європейського інструменту єврорегіонів, до якої активно залучаються і національні меншини. У статті приділено увагу правовому визначенню та регулюванню прав національних меншин Республіки Польща, визначено 
особливості та проблеми, з якими зіштовхувалася Польща у стосунках із національними меншинами. У статті визначено особливості правового поля регулювання прав національних меншин у Польщі, висвітлено діяльність специфічного дорадчого органу - Спільної комісії - як одного з інструментів ефективної співпраці між сторонами, а також висвітлено проблеми врегулювання надання регіональної мови Сілезії. У Республіці Польща живе чимало національних меншин: білоруси, росіяни, німці, чехи, словаки, роми, євреї та українці. Досвід Польщі є вкрай важливим для України не тільки через те, що ця держава є сусідом, але і у зв' язку з тим, що ця держава є стратегічним партнером. Попри це, Польща не робить чіткого розмежування між національними та етнічними меншинами, зокрема це стосується питання сілезців та лемків. Сілезці не визнаються етнічною меншиною, тоді як лемки, яких в Україні визнають як етнічну меншину, визначаються як національна меншина. Правове регулювання прав національних меншин у Польщі має доволі довгу історію та чимало позитивних моментів, які Україна могла би перейняти для себе. Метою статті є визначення позитивних та негативних сторін правового регулювання прав національних меншин у Республіці Польща.

Ключові слова: національні меншини, Республіка Польща, співробітництво, Спільна комісія, міжетнічні відносини, Україна, ЄС, правове регулювання.

\section{Summary}

Sokolovskyi O. B. Features of protection of the rights of national minorities in the Republic of Poland. Article.

In modern conditions, national minorities have become an integral part of international relations. After the collapse of the USSR and the Warsaw Pact, the Western powers were extremely worried that ethnic conflicts would take place on the territory of the former Russian Empire, which could escalate into full-scale wars. Despite the fears of the West, the countries of Central and Eastern Europe were able to get out of the situation very skillfully, and national minorities became the key to deeper cross-border cooperation and to establishing friendly relations with neighboring countries. The Republic of Poland is one of the most successful states in Central and Eastern Europe, including in ensuring the rights of national minorities. Poland is an active participant in cross-border cooperation in the framework of the European tools of Euroregions, to which national minorities are also actively involved. The article pays attention to the legal definition and regulation of the rights of national minorities of the Republic of Poland, identifies the features and problems faced by Poland in relations with national minorities. The article identified the features of the legal field of regulation of the rights of national minorities in Poland, and highlighted the activities of a special advisory body - the Joint Commission, as one of the tools for effective cooperation between the parties. There are many national minorities living in the Republic of Poland: Belarusians, Russians, Germans, Czechs, Slovaks, Roma, Jews and Ukrainians. Poland's experience is extremely important for Ukraine, not only because it is a neighbor, but also because it is a strategic partner. Nevertheless, Poland does not make a clear distinction between national and ethnic minorities, in particular the Silesians and Lemkos. Silesians are not recognized as an ethnic minority, while the Lemkos, who are recognized as an ethnic minority in Ukraine, are defined as a national minority. Legal regulation of the rights of national minorities in Poland has a long history and many positive aspects that Ukraine could adopt. The aim of the article is to determine the positive and negative aspects of the legal regulation of the rights of national minorities in the Republic of Poland.

Key words: national minorities, Republic of Poland, cooperation, Joint Commission, interethnic relations, Ukraine, EU, legal regulation. 